5. Карнышев А. Д. Природосообразность и психологическое здоровье личности. Сибирский психологический журнал. 2015. № 57. С. 141-156.

6. Литвин А., Мацейко О. Методологічні засади поняття «педагогічні умови». Педагогіка і психологія професійної освіти. 2013. № 4. С. 43-63.

7. Матвійчук А. В. Екологічна деонтологія: філософсько-методологічне осмислення наукових перспектив. Рівне : видав. О. Зень, 2014. 400 с.

8. Молчанюк О. В. Теоретико-методологічні засади виховання в майбутніх учителів біології ціннісного ставлення : дис. ... д-ра пед. наук : 13.00.07. Київ, 2020. 469 с.
9. Николина В. В., Белова Е. А., Говорухина Е. А. Добровольчество в проектной деятельности как фактор духов-но-нравственного воспитания студентов. Культурно-исторические традиции православия : материалы межд. конференции (г. Куремяэ (Эстония) 11-12 декабря, 2014 г.). Куремяэ, 2014. С. 189-194.

10. Пелех Ю. В. Формування вчителя майбутнього: аксіологічний контекст. Інноватика у вихованні. 2017. Вип. 6. С. 34-46.

11. Про вищу освіту: Закон України від 1 липня 2014 p. № 1556-VII. URL: https://zakon.rada.gov.ua/ laws/show/1556-18 (дата звернення: 17.03.2019).

Дата надходження до редакиіï: 23.07.2020 p.
УДК 370.191.12:340.131:616-047

DOI: 10.37026/2520-6427-2020-103-3-153-158
Наталія ХАРЧЕНКО, кандидат педагогічних наук, доиент кафедри природничо-математичної освіти Рівненського ОІППО

\title{
ПРАВОВІ ЗАСАДИ ФОРМУВАННЯ КОМПЕТЕНЦІЙ ІЗ ДОМЕДИЧНОЇ ДОПОМОГИ В ПЕДАГОГІЧНИХ ПРАЦІВНИКІВ ЗАКЛАДІВ ЗАГАЛЬНОЇ СЕРЕДНЬОЇ ОСВІТИ
}

У статті розглянуто нормативно-правову базу з питань збереження здоров'я людей у критичних для життя ситуаціях немедичними працівниками, зокрема педагогами, які зобов'язані володіти навичками з надання домедичної допомоги дітям. Доведено, щя вмінню надати домедичну допомогу сприяють різні способи навчання осіб, які не мають медичної освіти, але за своїми обов'язками повинні володіти основними практичними навичками щзодо рятування та збереження життя людини, яка перебуває у невідкладному стані.

Ключові слова: домедична допомога, нормативно-правова база домедичної допомоги, практичні навички, особи, які зобов 'язані надавати домедччну допомогу, навчання вчителів, якість домедичної допомоги.

В статье рассмотрена нормативно-правовая база, касаюшаяся вопросов сохранения здоровья людей в критических для жизни ситуациях немедииинскими работниками, в частности педагогами, которые обязаны владеть навыками по оказанию домедииинской помоши детям. Доказано, что умению оказать домедицинскую помощьь способствуют различные способы обучения лии, которые не имеют медииинского образования, но по своим обязательствам должны владеть основными навыками по спасению и сохранению жизни человека, который находится в неотложном состоянии.
Ключевые слова: домедицинская помощь, нормативно-правовая база домедицинской помощи, практические навыки, лица, которые обязаны предоставлять домедииинскую помощьь, обучение учителей, качество домедицинской помощи.

The development of the system of pre-medical aid in Ukraine was analysed from the point of view of the legal framework for pre-medical aid and Concept of quality standards of pre-medical competences of the European Union. The low level of knowledge of pre-medical aid, and as a consequence, deficiencies in the provision of pre-medical aid for participants in the educational process. The author paid attention to solving scientific and theoretical level issues related to the definition of the duties of the pedagogical workers to provide emergency, including pre-medical aid. The subject of research was the need to form algorithms of action practical skills and quality of pre-medical aid.

The analysis of the pre-medical aid regulatory framework has shown the imperfection, inconsistency and contradiction of the regulatory framework in the sphere of civil protection, labor protection and health care. World Health Organization notes that now the optimal model of learning practical skills in the legal field care in the world is not defined: these are trainings, fulltime training, courses, distance learning, self-education, experience exchange. 
It was found out that simulation training improves formation of pedagogical workers' competence. Additionally, this helps to them interest to subject learning and to learn algorithms of pre-medical aid providing in conditions that are close to real. To ensure the quality of training of pre-medical aid necessary to implement uniform training of all teachers the only course in compliance with rules of pre-medical aid, the systematic maintenance of acquired practical skills and knowledge.

Solving this task ensures the effectiveness of the direction of training is advanced training in the field of knowledge "Natural Education». Outlines the role of the Rivne Regional Institute of Postgraduate Pedagogical Education. Cooperation between the Department of Natural and Mathematical Education of our institute and a separate special medical unit "White Berets - Rivne» on the basics of self-help and mutual assistance, development of algorithms for pre-medical aid in critical situations has become traditional.

Key words: pre-medical aid, legal framework for pre-medical aid, practical skills, people obliged to provide pre-medical aid, training of teachers, quality of pre-medical aid.

Постановка проблеми. Здоров'я людини є одним iз пріоритетів державної політики України. У Конституції України (стаття 3) зазначається, що «людина, iii життя та здоров'я, честь і гідність, недоторканність та безпека визнаються найвищою соціальною цінністю» [12]. Право на життя та охорону здоров'я як невід'ємне право громадян визнається всіма цивілізованими країнами, зокрема у Європейській конвенції 3 прав людини (стаття 2) зазначається, що «... право кожного на життя охороняється законом» та гарантується людині як обов'язок держави [8]. Із 1948 року на міжнародному рівні право на охорону здоров'я гарантоване Загальною декларацією прав людини [9]. Ці документи і й сьогодні не втратили своєї актуальності, оскільки людина постійно знаходиться в умовах потенційних загроз, спричинених природними, соціальними, військовими або техногенними чинниками. За даними Всесвітньої організації охорони здоров'я (далі - ВООЗ), майже третина тих, хто постраждав під час катастроф у мирний час, за життєвими показниками потребують надання допомоги вже на місці події. Такою є домедична допомога, яку надають немедичні працівники у невідкладних для життя постраждалих випадках.

Доведено, що кожного п'ятого загиблого можна було б урятувати у разі надання йому своєчасної домедичної допомоги. Наведені вище дані свідчать про важливість формування та вдосконалення компетенцій осіб, які зобов'язані надавати таку допомогу [27]. Таким чином, під терміном «компетенція» розуміємо «вміння використати знання, навички, досвід у конкретних умовах, досягнувши при цьому максимально позитивного результату» [20, с. 153].

Законодавчі документи України свідчать про необхідність акцентувати увагу немедичних працівників, передусім педагогів, на актуальних питаннях збереження здоров'я та життя учасників освітнього процесу. Разом із тим, ментальність та інертність свідомості громадян суб'єктивно нівелюють питання ризиків і небезпек, а при їх виникненні стереотипи поведінки викликають ступор чи паніку, психологічну боязнь та пригадування механізмів надання домедичної допомоги лише на теоретичному рівні.
Як зазначає I. Кочін зі співавторами, «... наявна нормативно-правова база з питань екстреної медичної допомоги (далi - EMД) за умов надзвичайних ситуацій (далi $-H C)$ створювалася у той період становлення України, коли зміни в суспільстві та державі відбувалися стрімко та лавиноподібно, а процес їх законодавчого затвердження не завжди супроводжував події, а як наслідок - прийняті нормативні акти не завжди були всебічно обміркованими та обгрунтованими, а в окремих випадках - навіть суперечливими» [17, с. 63].

Таким чином, розуміння педагогічними працівниками закладів загальної середньої освіти (далі - 33СO) законодавчих основ формування та розвитку компетенцій із домедичної допомоги є тим чинником, який сприяє свідомому підходу до важливих питань збереження життя учасників освітнього процесу.

Аналіз наукових досліджень і публікацій. Проблеми організації навчання основам домедичної допомоги постраждалим досліджували як зарубіжні, так і вітчизняні вчені (А. Дубицький, I. Семенов, Л. Чепкий, І. Кочін, Г. Черняков, П. Сидоренко, Ю. Литвин, П. Сидоренко, Т. Пересипкіна, П. Волянський, М. Долгий, А. Макаренко, Н. Дрозденко, М. Стрюк, А. Саган, Д. Пантелі, В. Борковські, Л. Корженьовський, Л. Хофрейтор $[3 ; 7 ; 13 ; 16 ; 19 ; 29])$. Проте означені роботи здебільшого являють собою загальні огляди, тоді як питання щодо готовності вчителя надавати домедичну допомогу досі детально не аналізувалося і не було представлено.

Мета статті - на основі аналізу документів про охорону здоров'я окреслити законодавче підгрунтя для педагогічних працівників З3СО щодо необхідності знати, вміти та надавати домедичну допомогу.

Виклад основного матеріалу. За даними ВООЗ, третину від загиблих внаслідок нещасних випадків, можна було б урятувати за умов своєчасного надання їм домедичної допомоги, здійснення заходів щодо оживлення або своєчасної доставки до медичного закладу $[14$, с. 3$]$. Своєчасно та адекватно надана допомога постраждалому не лише рятує його життя, а й забезпечує швидке відновлення процесів життєдіяльності та повернення до працездатного стану. На жаль, в Україні середній показник смертності від надзвичайних ситуацій перевищує відповідні європейські показники у 20 разів. При цьому близько 76\% жертв помирають на догоспітальному етапі (у розвинутих державах світу - близько 28\%), а $80 \%$ летальних випадків пов'язані з неефективністю здійснення заходів на місці події [2].

Зауважимо, що відповідно до статистичних даних ВОО3, якщо швидка приїжджає впродовж 5 хв iз моменту виклику, то можливість зберегти життя постраждалого складає 80\%, а якщо протягом 15 хв і більше - лише 5\% [15, с. 113-114]. Усе це вказує на необхідність привернення уваги немедичних працівників до проблеми надання само- та взаємодопомоги в критичних для здоров'я ситуаціях.

Досвід багатьох країн світу свідчить, що для забезпечення своєчасного надання допомоги необхідно широко залучати немедичних працівників, які своїми адекватними діями на місці події зможуть урятувати життя постраждалих та мінімізувати негативні наслідки для здоров'я. Особливої уваги при цьому заслуговує питання формування практичних навичок iз надання домедичної допомоги вчителями. Акцент на ньому поставлено у зв'язку з уведенням у дію $3 a$ кону Украӥни «Про повну загальну середню освіту», 
частина 3 статmі 22 якого зобов'язує педагогічних працівників володіти навичками 3 надання домедичної допомоги дітям [25].

Розглянемо повноваження педагогічних працівників щодо організації дій із рятування життя учасників освітнього процесу, якщо така подія відбулася.

Безпосереднє визначення термінів подано у статті 3 Закону України «Основи законодавства України про охорону здоров'я» та статті 1 Закону України "Про екстрену медичну допомогу», зокрема зазначено, що «невідкладний стан людини - це раптове погіршення фізичного або психічного здоров'я, яке становить пряму та невідворотну загрозу життю та здоров'ю людини або оточуючих іiї людей і виникає внаслідок хвороби, травми, отруєння або інших внутрішніх чи зовнішніх причин», а «домедична допомога» - «невідкладні дії та організаційні заходи, спрямовані на врятування та збереження життя людини у невідкладному стані та мінімізацію наслідків впливу такого стану на її здоров'я, що здійснюються на місці події особами, які не мають медичної освіти, але за своїми службовими обов'язками повинні володіти основними практичними навичками 3 рятування та збереження життя людини, яка перебуває у невідкладному стані, та відповідно до закону зобов'язані здійснювати такі дії та заходи» [18; 22].

Звернемо увагу, що статтею 12 Закону Украӥни «Про екстрену медичну допомогу» визначено: «особами, які зобов'язані надавати домедичну допомогу людині у невідкладному стані, є: рятувальники аварійно-рятувальних служб, працівники державної пожежної охорони, поліцейські, фармацевтичні працівники, провідники пасажирських вагонів, бортпровідники та інші особи, які не мають медичної освіти, але за своїми службовими обов'язками повинні володіти практичними навичками надання домедичної допомоги» [22]. Пересічний громадянин у цьому переліку професій не знайде вчителів, однак визначені законом посади $є$ такими, що їх спеціалістів можна ідентифікувати за спеціальним одягом чи відповідними шевронами. Цього, однозначно, неможливо здійснити стосовно педагогічних працівників, однак педагоги є саме тими «іншими особами, які не мають медичної освіти, але за своїми службовими обов'язками повинні володіти практичними навичками надання домедичної допомоги».

Статтею 10 згаданого вище Закону окреслені обов'язки громадян України «вживати ... заходів для забезпечення надання екстреної медичної допомоги іншим особам, які знаходяться у невідкладному стані».

Важливо також пам'ятати, що частина 2 cmammi 21 Кодексу ичивільного захисту України покладає на всіх громадян України обов'язки: «1) дотримуватися правил поведінки, безпеки та дій у надзвичайних ситуаціях; 3) вивчати способи захисту від надзвичайних ситуацій та дій у разі їх виникнення, надання домедичної допомоги постраждалим, правила користування засобами захисту; 7) виконувати правила пожежної безпеки, забезпечувати будівлі, які їм належать на правах приватної власності, первинними засобами пожежогасіння, навчати дітей обережному поводженню 3 вогнем» [11].

При цьому стаття 15 Закону України «Про екстрену медичну допомогу» регламентує притягнення до відповідальності осіб, винних у не вчиненні дій зі спасіння життя постраждалих. Зокрема, вони «... несуть дисциплінарну, адміністративну, кримінальну або цивільно-правову відповідальність за: ненадання без поважних причин на місці події домедичної допомоги або необгрунтовану відмову в іiі наданні; несвоєчасне надання екстреної медичної допомоги або створення перешкод у іiї наданні; невиконання без поважних причин розпоряджень оперативно-диспетчерської служби центру екстреної медичної допомоги та медицини катастроф або бригади екстреної (швидкої) медичної допомоги щодо надання необхідної невідкладної медичної допомоги пацієнту, який перебуває у невідкладному стані, що загрожує життю такого пацієнта» [22].

Прийняття Верховною Радою України у січні 2020 року Закону Украӥни «Про повну загальну середню освіту» підкреслило вагомість знань, практичних навичок та вмінь педагогічними працівниками надавати домедичну допомогу.

Наголосимо, що ці ж положення виписані й у посадовій інструкції вчителя [21], а статтею 18 Закону Украӥни «Про охорону прачіi» визначено, що «працівники під час прийняття на роботу і в процесі роботи повинні проходити за рахунок роботодавця інструктаж, навчання з питань охорони праці, з надання першої медичної допомоги потерпілим від нещасних випадків і правил поведінки у разі виникнення аварії» [24].

Таким чином, уміння надавати домедичну допомогу стає невід'ємною складовою професійної діяльності педагогічних працівників.

У той же час, за дослідженнями вчених (Ю. Скалецький та ін.), значна частина молоді України (понад 58\%) практично не володіють навичками надання домедичної допомоги та правилами поведінки в надзвичайних ситуаціях [26, с. 17]. Схожі результати надає Н. Ількевич [10], зокрема автором встановлено, що лише $35 \%$ респондентів адекватно реагують на ймовірні небезпеки, хоча понад $80 \%$ опитаних вказали, що людина повинна сама дбати про своє здоров'я та безпеку. Крім того, подаються дані (понад 59,8\% опитаних) про брак знань щодо алгоритмів поведінки у разі виникнення надзвичайних ситуацій, а також відомості про те, що 70\% респондентів виявили бажання поглибити свої знання 3 домедичної допомоги та пройти практичний курс із виживання в екстремальних умовах [10, с. 55-56].

Заслуговують на увагу дослідження С. Білошицького [1]. Він зауважує, що 95,6\% керівних кадрів проводять для працівників навчання та перевірку знань 3 охорони праці (безпеки життєдіяльності), однак при цьому найвищі показники обізнаності були засвідчені лише на рівні 26,3\% та 27,4\% відповідно вчителями фізики та інформатики. 35,5\% педагогічних працівників уміють застосовувати засоби пожежогасіння, i лише 24,4\% учителів знають про порядок дій із надання домедичної допомоги за потреби. Автор зазначає, що на запитання «Чи зможете ви в разі необхідності надати долікарську допомогу?» позитивну відповідь дали $37,8 \%$ педагогічних працівників, а майже половина опитаних $(47,2 \%)$ утрималися від відповіді на це запитання. С. Білошицький підсумовує, що рівень підготовленості вчителів до само- та взаємодопомоги зі спасіння життя $\epsilon$ доволі низьким, тоді як керівники закладів освіти, як правило, перебільшують рівень знань і навичок своїх підлеглих із питань охорони праці та безпеки життєдіяльності [1, с. 16].

Ще більш приголомшливі результати подає Л. Гудзевич, зокрема зазначає, що $73 \%$ опитаних мають хибні уявлення про правила домедичної допомоги, 
а переважна більшість респондентів (86\%) мають лише теоретичні уявлення та знання. Метод муляжування (штучно відтворених реальних пошкоджень людини на манекенах або волонтерах) вивчали та практично відтворювали лише одиниці з опитаних [5, с. 139-140]. Після проходження навчань практичного характеру низький рівень психологічної готовності до надання домедичної допомоги був характерним усього для 2,6\% учасників експерименту. Зважаючи на це, авторка стверджує, що лише практичні заняття, відпрацювання навичок роботи, моделювання та відтворення типових ситуацій зі спасіння життя людей «у подальшому сприятиме покращенню виконання професійних завдань в екстремальній ситуації на етапі надання домедичної допомоги» [5, с. 140]. Крім того, Л. Гудзевич підкреслює, що саме «практична підготовка має ... неабияке психологічне значення для формування психоемоційної толерантності, ... блокування деструктивних емоційних переживань, ... найбільш повного засвоєння матеріалу» [4]. Погоджуємося із дослідницею стосовно того, що терміни «знання» $\mathrm{i}$ «навички», що застосовуються до домедичної допомоги, тотожні 3 поняттями «абстрактне» $\mathrm{i}$ «конкретне»: лише теоретичних знань тут $\epsilon$ недостатньо, практичне відпрацювання алгоритмів дій призводить до набуття компетенцій із домедичної допомоги, перетворює знання в навички, що виконуються на підсвідомому рівні. Зважаючи на пріоритети шкільного життя, констатуємо: вміння вчителя надавати домедичну допомогу напряму пов'язане 3 організацією безпечного шкільного середовища.

Розглянемо напрями формування та розвитку в педагогічних працівників компетенцій із домедичної допомоги. До них передусім варто віднести:

1. Тематичні навчання, тренінги, сертифіковані курси з домедичної допомоги.

2. Онлайн-курси від установ та організацій, зокрема органів управління освітою.

3. Організація відповідних навчань у межах закладу освіти із залученням фахівців.

4. Навчання домедичній допомозі в рамках навчальної програми підвищення кваліфікації за напрямом педагогічної діяльності.

5. Взаємо- і співнавчання через, наприклад, роботу методичного об'єднання вчителів, самоосвіта.

Лідерами з підготовки та підвищення кваліфікації немедичних працівників є заклади вищої освіти MO3 України, навчально-тренувальні відділи центрів екстреної медичної допомоги та медицини катастроф, навчально-тренувальні відділи Товариства Червоного Хреста, інші ліцензовані підрозділи. Серед таких варто виокремити: Всеукраїнську раду реанімації та екстреної медичної допомоги, Центр симуляційного навчання ТНМУ, Центр спеціальної підготовки Олега Картавого, Всеукраїнську спілку парамедиків, Мальтійську службу допомоги, 44 Навчальний Центр/«EMSA - Ukraine», Курси першої домедичної допомоги «САВ», Всеукраїнську громадську організацію «Українська Служба Порятунку» та ін.

Особливості організації освіти із застосуванням технологій дистанційного навчання дає сьогодні змогу педагогічним працівникам пройти віддалене навчання, зокрема за програмами онлайн-курсу «Домедична допомога» від ГО «Смарт Освіта» та EdEra, дистанційного навчання «Курс ПМД онлайн», онлайн-курсу BFA (Basic First Aid), онлайн-курсу 3 надання домедичної допомоги від Національного молодіжного освітнього проєкту Safety Park.
Розуміючи пріоритетність збереження здоров'я та життя учасників освітнього процесу, кафедрою природничо-математичної освіти Рівненського обласного інституту післядипломної педагогічної освіти постійно проводиться робота 3 підвищення кваліфікації педагогічних кадрів, передусім із питань домедичної допомоги. Упродовж останніх шести років питання домедичної допомоги висвітлено на лекційно-практичних заняттях, тренінгах, спецкурсах із тем: «Ocнови домедичної допомоги», «Законодавство України в галузі цивільного захисту та екстреної медичної допомоги», «Дії населення у надзвичайних ситуаціях та порядок надання домедичної допомоги», «Основи надання домедичної допомоги постраждалим», «Самота взаємодопомога у критичних для здоров'я ситуаціях», «Основи законодавства України про охорону здоров'я для немедичних працівників», «Основи домедичної допомоги як реалізація наскрізної змістової лінії «Здоров’я і безпека». Для цього викладачі кафедри, які проводять такі заняття, постійно підвищують власну кваліфікацію та проходять відповідні тренінги й курси, наприклад, серед останніх пройдених ними навчання за сертифікованою програмою Всеєвропейської Ради Реанімації The European Resuscitation Council курсу BLS (Basic Life Support).

Таким чином, упродовж 2014-2020 років понад п'ять тисяч учителів із предметів природничого циклу у ході підвищення кваліфікації були долучені до різних форм навчання з домедичної допомоги. Основу лекційного матеріалу складало законодавство України в галузі охорони здоров'я для немедичних працівників, наказ Міністерства охорони здоров'я України «Про затвердження порядків надання домедичної допомоги особам при невідкладних станах» 16.06.2014 № 398, а практичною складовою слугувала розробка алгоритмів, моделювання ситуацій та відпрацювання дій у критичних ситуаціях $[6 ; 23 ; 28 ; 30]$. До проведення практичних занять також залучалися висококваліфіковані медичні фахівці.

Важливою у навчальній та позааудиторній роботі $\epsilon$ налагоджена співпраця з установами та організаціями, що проводять відповідні заходи в галузі охорони здоров'я, зокрема окремим медичним підрозділом спеціального призначення «Білі берети - Рівне», ГО «Рівне-ТАКМЕД», Рівненською обласною станцією переливання крові, Обласним центром профілактики та боротьби зі СНІДом, Обласним центром громадського здоров'я, Обласною науково-методичною комісією з цивільного захисту, безпеки життєдіяльності та основ медичних знань, Навчально-методичним центром цивільного захисту та безпеки життєдіяльності Рівненської області.

Спільна робота стала основою діяльності тимчасового науково-дослідного колективу кафедри природничо-математичної освіти Рівненського ОІППО «Базова підтримка життя: модель безпеки людини у сучасному світі». Викладачі кафедри здійснювали науково-методичне консультування та експертизу ефективності моделі «Керівник суб'єкта господарювання, компетентний у сфері цивільного захисту» за програмою досліджень ТНДК Навчально-методичного центру цивільного захисту та безпеки життєдіяльності Рівненської області з теми «Компетентнісний підхід до організації практичної підготовки працівників суб' єктів господарювання до дій в умовах надзвичайних ситуацій». Одним із підсумків спільної діяльності закладів слугував проведений у жовтні 2019 року 
на базі Рівненського ОІППО Всеукраїнський науково-практичний семінар ДСНС та МОН України «Організація діяльності базових (опорних) закладів освіти з безпеки життєдіяльності». Членами ТНДК була представлена доповідь «Організація підвищення кваліфікації педагогічних працівників 3 питань цивільного захисту», в рамках якої озвучувалися актуальні питання організації навчання педагогічних працівників 3 домедичної допомоги.

Сьогодні на усіх рівнях визнаються пріоритети домедичної допомоги. Однак педагогічні працівники найчастіше проходять навчання 3 домедичної допомоги за власними бажанням і використовуючи власні кошти. Протиріччя в законодавчих документах ставить допоки нерозв'язану проблему: як створити належні умови та навчити всіх педагогічних працівників їхньому прямому обов'язку - володіти навичками 3 надання домедичної допомоги дітям, а у випадку виникнення екстрених ситуацій - максимально кваліфіковано дотримуватися порядків надання домедичної допомоги постраждалим.

Висновки. Таким чином, опрацьовані нами джерела свідчать про необхідність подальшого вивчення питання щодо формування та розвитку в педагогічних працівників компетенцій із домедичної допомоги. Наявні проблеми та законодавчі протиріччя не дозволяють педагогам повною мірою реалізувати можливості навчання основам домедичної допомоги у ході підвищення кваліфікації.

Подальші дослідження у даному напрямі вбачаємо в: обгрунтуванні організації навчання педагогічних працівників закладів загальної середньої освіти практичним навичкам надання домедичної допомоги (останнє, на наш погляд, є можливим при розробці відповідних методичних матеріалів саме для учасників освітнього процесу на основі моніторингу знань та вмінь, психологічної готовності та розуміння важливості проблеми збереження життя дітей); аналізі чинників, які впливають на формування (розвиток) у педагогічних працівників компетенцій із домедичної допомоги та ефективність надання домедичної допомоги в закладі освіти; вивченні закордонного досвіду з організації навчання педагогів умінню надавати домедичну допомогу та нормативно-правових основ регулювання питань збереження здоров'я і життя людей немедичними працівниками.

\section{СПИСОК ВИКОРИСТАНОЇ ЛІТЕРАТУРИ}

1. Білошицький С. В. Проблеми охорони праці та безпеки життєдіяльності очима педагогів (за матеріалами регіонального соціологічного дослідження). Проблеми ияиільного захисту населення та безпеки життєдіяльності: сучасні реалії України: матер. III Всеукр. заочної наук.-практ. конф., м. Київ, 21 квіт. 2017 р. / ред. кол. : С. В. Шмалєй [та ін.] ; Мін-во освіти і науки України, Нац. пед. ун-т ім. М. П. Драгоманова [та ін.]. Київ : НПУ ім. М. П. Драгоманова, 2017. C. $15-16$.

2. Волянський П. Б., Макаренко А. М. Домедична допомога як складова сучасної системи реагування на надзвичайні ситуації. Державне управління: удосконалення та розвиток. 2015. № 12. URL : http:// www.dy.nayka.com.ua/?n=12\&y=2015 (дата звернення: 11.05.2020).

3. Волянський П. Б. Шляхи розвитку навчання 3 домедичної допомоги в Україні. Врачебное дело. 2017. № 5/6. С. 175-179.
4. Гудзевич Л. С., Колібабчук А. В. Особливості формування навичок першої допомоги в умовах професійної підготовки майбутніх учителів. Naukowa przestrzeń Europy - 2015 : Materiały XI Międzynarodowej naukowipraktycznej konferencji, Przemyśl, 07-15 kwietnia 2015 r. Nauka i studia. 2015. Vol. 21. Medycyna. URL: https://bit. ly/2ObomX9 (дата звернення : 22.06.2020).

5. Гудзевич Л. С. Форми та методи навчання студентів домедичної допомоги. Сучасні проблеми біологічної науки та методика ї̈ викладання у закладах вищеої освіти : збірник наукових праць звітної наукової конференції викладачів за 2017/2018 н. р. Вінниця : ТОВ «Нілан-ЛТД», 2018. С. 135-145.

6. Домедична допомога. Top Guard security. URL: https://bit.ly/2BYujUJ (дата звернення: 30.06.2020).

7. Дубицький А. Е., Семенов I. О., Чепкий Л. П. Медицина катастроф. Київ : Здоров'я, 1993. 462 с.

8. Свропейська конвенція з прав людини. URL: https://www.echr.coe.int/Documents/Convention_UKR. pdf (дата звернення: 17.06.2020).

9. Загальна декларація прав людини. URL: https://bit.ly/2CnvPj2 (дата звернення: 17.06.2020).

10. Ількевич Н. С. Аналіз стану культури безпеки життєдіяльності студентів вищих навчальних закладів. Проблеми цивільного захисту населення та безпеки життєдіяльності: сучасні реалії України : матер. III Всеукр. заочної наук.-практ. конф., м. Київ, 21 квіт. 2017 р. / ред. кол. : С. В. Шмалєй, С. П. Гвоздій, О. В. Дашковська [та ін.] ; МОН України, Нац. пед. ун-т ім. М. П. Драгоманова [та ін.]. Київ : НПУ ім. М. П. Драгоманова, 2017. С. 55-56.

11. Кодекс цивільного захисту України. Відомості Верховної Ради. 2013. № 34-35. С. 458. URL: https://zakon.rada.gov.ua/laws/show/5403-17\#Text (дата звернення : 04.06.2020).

12. Конституція України. Відомості Верховної Ради Украӥни. 1996. № 30. C. 141. URL: https://bit. ly/3frGXtO (дата звернення : 17.06.2020).

13. Кочін I. В., Черняков Г. О., Сидоренко П. І. Медицина катастроф : виробниче видання / за ред. I. В. Кочіна. Київ : Здоров’я, 2008. 724 с.

14. Методичні вказівки до виконання практичної роботи 3 дисципліни «Безпека життєдіяльності» на тему «Надання першої долікарської допомоги потерпілому» для студентів за всіма напрямами підготовки НУВГП денної та заочної форми навчання / Г. І. Туровська, І. М. Риженко. Рівне : НУВГП, 2012. 42 с.

15. Неділько Р. В. Удосконалення механізмів державного управління системою освіти середнього медичного персоналу в Україні : дис... канд. наук із держ. упр. : 25.00.02 / Класичний приватний університет. Запоріжжя, 2018. 205 с. URL: https://bit. ly/3fa33Bg (дата звернення: 15.04.2020).

16. Нормативно-правове регулювання надання домедичної допомоги немедичними працівниками / П. Б. Волянський, М. Л. Долгий, А. М. Макаренко та ін. Інвестииії: практика та досвід. 2016. № 3. С. 63-66.

17. Організаційні та медичні аспекти екстреної медичної допомоги за умов надзвичайних ситуацій (аналітичний огляд сучасної нормативно-правової бази України) / І. В. Кочін, О. М. Акулова, П. І. Сидоренкота ін. Украӥна. Здоров'я начіiї. 2013. № 1 (25). С. 63-69.

18. Основи законодавства України про охорону здоров'я : Закон України від 19 лиспоп. 1992 р. № 2801-XII. Відомості Верховної Ради України. 1993. № 4. C. 19. URL: https://zakon.rada.gov.ua/laws/ show/2801-12\#Tехt (дата звернення: 04.06.2020). 
19. Пересипкіна Т. В., Сидоренко Т. П., Пересипкіна А. М., Кіндрук М. О. Медична допомога дітям у навчальних закладах: стан, проблеми та перспективи розвитку. Здоровье ребенка. 2018. Т. 13. № 7. С. 698703. URL: http://childshealth.zaslavsky.com.ua/article/ view/148924 (дата звернення: 26.05.2020).

20. Писаревська О. В. Методологічні аспекти формування стратегічної компетентності майбутніх юристів в університетах Франції. Молодь $і$ ринок. Дрогобич, 2019. Вип. 6 (173). С. 152-158.

21. Посадова інструкція вчителя школи. Охрана труда и техника безопасности в школе. URL: https:// ohrana-tryda.com/posadova-vchitel (дата звернення: 11.06.2020).

22. Про екстрену медичну допомогу : Закон України від 05 лип. 2012 р. № 5081-VI. Відомості Верховної Ради. 2013. № 30. С. 340. URL: https://zakon. rada.gov.ua/laws/show/5081-17\#Text (дата звернення: 04.06.2020).

23. Про затвердження порядків надання домедичної допомоги особам при невідкладних станах : наказ Міністерства охорони здоров'я України від 16 черв. 2014. № 398. URL : https://zakon.rada.gov.ua/laws/ show/z0750-14\#Text (дата звернення: 15.05.2020).
24. Про охорону праці : Закон України від 14 жовт. 1992 р. № 2694-XII. Відомості Верховної Ради. 1992. № 49. C. 668. URL: https://zakon.rada.gov.ua/ laws/show/2694-12\#Tеxt (дата звернення: 04.06.2020).

25. Про повну загальну середню освіту : Закон України від 16 січ. 2020 р. URL: https://zakon.rada.gov. ua/laws/show/463-20\#Text (дата звернення: 04.06.2020).

26. Скалецький Ю. М., Бирюков Д. С., Мартюшева А. А., Яценко Л. Д. Проблеми впровадження культури безпеки в Україні. Київ : НІСД, 2012. 17 с.

27. Халмурадов Б. Д., Волянський П. Б. Медицина надзвичайних ситуацій : підручник. Київ : Центр навчальної літератури, 2016. 206 с.

28. Чуприна О., Жилін Т. Домедична підготовка : курс лекцій. Київ : Нац. акад. внутр. справ, 2017. 120 с.

29. Sagan A, Panteli D., Borkowski W. et al. Poland: Health system review. Health Systems in Transition. 2011. № 13 (8). P. 1-193.

30. Summary of the main changes in the Resuscitation Guidelines ERC GUIDELINES 2015 / The European Resuscitation Council Guidelines for Resuscitation 2015. URL: https://cprguidelines.eu/ (дата звернення: 27.05.2020).

Дата надходження до редакиіï: 10.07.2020 p. 